\title{
Entrepreneurial Culture and Financial Education Between Students of the Veracruzana University, Veracruz Region
}

\author{
Ignacio Ortiz Betancourt
}

Veracruzana University

Mexico

\begin{abstract}
Entrepreneurial culture and financial education stand out as two fundamental issues on the international agenda, since these elements are considered in favor of the efficient use of financial resources, as well as the identification of opportunities for the development of self-employment projects, contributing to local economic growth.According to the National Commission for the Protection and Defense of Financial Services Users (CONDUSEF, 2012), financial education can be defined as the set of actions that imply learning to manage money better, being foresighted, consuming in a rational way, And learn to invest, know how to take care of your assets and use financial products and services with responsibility.Similarly, Smyth (2011) points out that financial education is the process by which consumers improve the understanding of financial products and acquire a greater understanding of financial risks and market opportunities, by making economic decisions with Information. In addition, he points out that an important part of our decisions is associated with financial behavior, which directly impacts his personal and family environment, from the search for funding for studies to planning for retirement. Thus, having an adequate financial education will favor an intelligent selection of financial products, based on well-informed decisions.
\end{abstract}

Keywords: Entrepreneurial Culture and Financial Education Between Students of the Veracruzana University, Veracruz Region

\section{Introduction}

\section{Background}

The benefits of having an adequate financial education also extend to the national economic level, since, as BBVA (2015) points out, greater economic and financial education contributes to explain the level of financial development in the country, and Which ultimately leads to lower inequality. In this way, having policies to promote these issues would contribute to reducing inequality by allowing large groups of the population of a country to access financial markets to make their savings profitable. This can also favor an improvement and development of the domestic financial market and consequently contribute to economic growth.

However, the picture of financial education in Mexico is unfavorable, since, as mentioned by BANAMEX and UNAM (2008) in the results of the First Survey on Financial Culture in Mexico, there is, in the majority of the population, A medium-term or long-term vision in matters related to finances. In addition, an incipient "control and expenditure planning" culture was identified. This is because, overall, about one in five households had a record of expenditures or planned income, debt and household savings. 
In this sense, it is observed that in Mexico there is an environment with gaps and gaps in terms of financial culture, both in terms of training and information, which is more evident among the rural population and sectors of lower education and socioeconomic level, causing Serious consequences, among which are the lack of planning in the control of expenses, income and debt, lack of savings and a culture of foresight, which undoubtedly compromises the stability of most Mexican families.

In addition to this, this lack of financial education has repercussions in the area of business, and especially among the projects of micro, small and medium enterprises (MSME's) and entrepreneurs, which, according to Carton, Hofer and Meeks (1998) are those people with the ability to identify market opportunities to create companies and thus generate value.

This is evident since, as Lederman, Messina, Pienknagura and Rigolini (2014) state that there is a large gap between the ability to access financing between large companies and the rest, with larger ones being widely favored. This difficulty faced by MSMEs to raise capital also implies greater demands on their use, which undoubtedly requires an adequate level of financial education. In addition, Lederman et al. point out that it is possible that this access barrier to financing that new companies experience is negatively affecting the entrepreneurial potential of Latin America and the Caribbean.

Also, Marin (2014) stresses that it is important for entrepreneurs to have the ability to evidence their knowledge in financial matters, because in this way they can overcome the challenges of the market. Similarly, Di Costanzo (2013) argues that a company that begins operations without basic financial education has a high chance of failure, while those that incorporate good financial practices increase their chances of remaining in the market. Thus, financial education has a great influence on the success of entrepreneurial projects.

Once the importance of the topics of financial education and entrepreneurship in the national and international agencies has been identified, it is necessary to identify one of the main spaces where strategies can be designed and implemented in favor of these topics: the university. This, as mentioned by Neck (2014), is because education is an essential factor to start a business, and therefore the university gives the student the space where he can practice the venture, and at the same time can learn to deal with the uncertainty of the market, which is part of the world of entrepreneurship.

Thus, universities have a fundamental role in the process of training competent individuals to meet the demands of an increasingly competitive labor market, in which they will have to make use of financial tools and entrepreneurial skills. However, Lopez (2010) emphasizes the fact that the level of schooling is not directly related to the degree of financial education of individuals.

Based on the above, there is interest in identifying the level of financial education and how widespread is the entrepreneurial culture among university students in our country. However, given the large potential population to be addressed during this project, we intend to limit our space to the context of our federal entity, in which the Veracruzana University represents the main house of studies given its presence and coverage in twenty-eight municipalities distributed in five regions: Xalapa, Veracruz, Orizaba-Córdoba, Poza Rica-Tuxpan and Coatzacoalcos-Minatitlán.

Given these premises, the following research question that will lead to the development of this project is proposed: which is the level of financial education and entrepreneurial culture among the students of the Veracruz University, Veracruz region?

Then, this work aims to identify the level of entrepreneurial culture and financial education among the university students of the different areas of knowledge of the Veracruz University, Veracruz Region. Next, a series of arguments that validate the pertinence of this work are presented.

\section{Justification}

The close relationship that exists between the level of financial education and the level of success of entrepreneurial 
projects is very important since they affect the pattern of economic growth in emerging economies. This is why the InterAmerican Development Bank (IDB, 2014) has emphasized among senior officials of ministries and agencies of Science, Technology and Innovation of Latin America and the Caribbean the need to discuss public policies that promote entrepreneurship. This institution also continues to promote the dissemination of financial education programs, since these have a fundamental impact on the well-being of citizens (IDB, 2015).

This IDB effort can build on the widely accepted premise that closely links business to economic growth and productivity (Lupiáñez, Priede \& López-Cózar, 2014). In this sense, they emphasize that the business aggregate and the creation of new units represent the engine of the economy of the industrialized countries (García, Martínez \& Fernández, 2010; Galindo \& Méndez, 2011). Similarly, Álvarez, Giraldo and Martínez (2014) point out that the sum of entrepreneurial entrepreneurship projects contribute to social and economic development at local and national levels; Being the local area where the positive effects are more evident, which translate into an increase in the level of employment and income of the population.

However, Lupiáñez, Priede and López-Cózar also point out the fact that among the empirical evidence there are no uniform results that allow us to conclusively confirm this premise, but these vary based on the context and the indicators used to quantify this relationship.

In addition, the premise that the lack of financial education has an impact on the development of young entrepreneurs (Singer, 2016) represents another area for further research on this subject, since, as Lederman et al. (2014), it is difficult to conclude that the lack of access to financing is one of the main constraints of innovation and the development of entrepreneurial projects.

Based on the above, the development of this work acquires relevance since, according to CONDUSEF (2013), there is a severe delay in our country in the area of financial education, which is evident since due to the lack of information people do not know the advantages or disadvantages they can get from their use.

Similarly, the National Entrepreneur Observatory (2013) emphasizes that in our country, despite the fact that entrepreneurs and MSME's generate a significant amount of jobs and income for the country, they suffer from a series of weaknesses; among which are: difficulty accessing financing, lack of knowledge on the subject and low productivity.

Thus, raised these needs we recognize the importance of continuing and contributing to the analysis with concrete proposals on these issues, since they represent areas of opportunity for economic growth and social development in our country.

In addition, these topics will remain strategic on the international agenda, as the World Bank (2015) states that entrepreneurship and financial culture represent two of the major development tools. Added to this, in the context of the State of Veracruz, Mexico, there is little to no research regarding the level of financial education and entrepreneurial culture, jointly, among university students.

\section{Empirical framework}

According to Siciliano (2009), cited by Khwaja (2009), financial knowledge is essential to promote sustainable projects; then, entrepreneurs must develop a series of financial competences to increase their business skills; similarly, Bruhn and Zia (2011) point the role of training to enhance entrepreneurial projects; in this case, they found that individuals that attended some business skills courses improved their financial knowledge, developed new business strategies and better personal and business financial practices.

Besides, the site Small Business BC (2016) mentions that financial literacy has gained attention not just from government agencies, but universities and high education institutions have developed a series of research projects to identify the status of students in this topic among countries. Also, it is mentioned that small business owners which have financial skills are more competitive and could manage changes in the economic environment in a better way; also, they could offer better support to their employees and even start training them in this area. 
In relation to the relationship between entrepreneurship and financial literacy, Njoroge (2013) found that successful entrepreneurs had strong financial skills and got grades above average; on the opposite side, less successful entrepreneurs showed low financial skills and many of them ran informal businesses. Added to this, Nunoo \& Andoh (2012) studied the implication of financial literacy as a way to develop sustainable business; according to them, financial knowledge and skills could help MSME's owners to access to better financial services, providing new options to support business performance. In their results, they stress that owners with high financial knowledge had access to better financial services.

Also, Mabhanda (2015) found that MSME's owners with low financial literacy levels had less ability to cope with economic environment changes and had poor performance at financial and managerial tasks, driving to less informed decision making.

Based on the above, it is observed that financial literacy has a positive impact on entrepreneurship as high financial skills could enhance MSME's performance.

\section{Methodology}

The present study is based on the development of a descriptive, non-experimental and cross-sectional research. This, since it is intended to identify the level of entrepreneurial culture and financial education among the population under study; In addition, this work is non-experimental since the variables involved in its development are not manipulated, and of a cross-sectional type since the data was collected in a single moment.

Regarding the characteristics of the information obtained and the techniques for its processing and subsequent interpretation, this study is considered to be of a quantitative type.

In order to order to carry out the field investigation phase and compile the information that allows us to reach the aim of this work, a questionnaire was designed considering the instruments presented by Tiftik (2014) and Yılmaz \& Sünbuil (2008), quoted in Tiftik, which assess entrepreneurial skills. To measure financial literacy, the questionnaire designed by Atkinson and Messy (2012) was reviewed and adapted for this context.

In terms of population, the universe is represented by the total number of students at the Veracruzana University (UV) region of Veracruz. In this sense, the online report issued by the Directorate of Institutional Planning of the UV for the 20152016 cycle, yields a total of 11,181 undergraduate students distributed in thirty educational programs. In order to manage such a large population, only students from Management Faculty were considered, and a sample size of 89 students was surveyed, based on non-probabilistic sampling for convenience. As a inclusion criteria, only students who have passed more than $75 \%$ of total credits were considered, in order to guarantee that must have taken courses that promote math, financial and entrepreneurial business skills.

\section{Results}

After analyzing the answers got from surveyed students, next results were got:

Table 1. Survey results

\begin{tabular}{|l|l|l|l|}
\hline \multicolumn{2}{|l|}{ Entrepreneurial skills } & \multicolumn{2}{l|}{ Financial literacy } \\
\hline Low & $2.25 \%$ & Low & $24.72 \%$ \\
\hline Medium & $28.09 \%$ & Medium & $60.67 \%$ \\
\hline High & $55.06 \%$ & High & $14.61 \%$ \\
\hline Very high & $14.61 \%$ & Very high & $0.00 \%$ \\
\hline Total & $100.00 \%$ & Total & $100.00 \%$ \\
\hline & & \multicolumn{2}{c}{} \\
\end{tabular}


As shown in Table 1, most students had a high level of entrepreneurial skills and a medium level of financial literacy; also, it is important to mention that just $2.25 \%$ had low entrepreneurial skills and no one showed a very high financial literacy level.

Considering the correlation index between Entrepreneurial skills and financial literacy, a value of 0.27 was found; then, financial education showed a direct but low effect on entrepreneurial skills.

\section{Conclusion}

As many of authors reviewed in this study have stated, financial literacy has a positive effect on entrepreneurial skills. In the case of Management Faculty students from Veracruzana University surveyed, similar relation was found but not as strong as expected. Nevertheless, this is an important step to provide information on a topic not documented in our context and that could be helpful to design university policies addressed to enhance financial and entrepreneurial skills among students, increasing their chances to start a successful business project.

\section{References}

[1] Álvarez, A., Giraldo, O., \& Martínez, B. (2014). Emprendimiento, factor clave para el crecimiento económico. Algunos elementos de casos en Colombia y otros estudios. Escenarios: empresa y territorio, ND, 1-16.

[2] Atkinson, A. \& Messy, F. (2012). Measuring Financial Literacy: Results of the OECD / International Network on Financial Education (INFE) Pilot Study. OECD Working Papers on Finance, Insurance and Private Pensions..No..15,.OECD.Publishing,.Paris..http://dx.doi.org/10.1787/5k9csfs90fr4-en

[3] BANAMEX \& UNAM. (2008). Primera Encuesta sobre Cultura Financiera en México. (1, 1-36), México, D.F.: Educación Financiera BANAMEX.

[4] BBVA. (2015). Una educación financiera y económica global ayuda a reducir la desigualdad de un país. 17 de febrero de 2016, de BBVA Sitio web: https://info.bbva.com/es/noticias/economia/consumo/una-educacionfinanciera-y-economica-global-ayuda-a-reducir-la-desigualdad-de-un-pais/

[5] Bruhn, M. \& Zia, B. (2011). The Impact of Business and Financial Literacy Training for Young Entrepreneurs in Bosnia-Herzogovina. The World Bank. Develpment

Research..Available.at:.http://econ.worldbank.org/external/default/main?theSitePK=469382\&contentMDK=229 05026\&menuPK $=476752 \&$ pagePK $=64165401 \&$ piPK $=64165026$

[6] Carton, R., Hofer, C., \& Meeks, M. (1998). The entrepreneur and entrepreneurship: Operational definitions of their role in society. Annual International Council for Small Business Conference, Singapur.

[7] Di Costanzo, M. (2013). Educación financiera, clave para supervivencia de Pymes. 20 de febrero de 2016, de Forbes México Sitio web: http://www.forbes.com.mx/condusef-dara-impulso-a-mipymes-y-emprendedores/

[8] Galindo, M. \& Méndez, M. (2011). Innovación y crecimiento económico: factores que estimulan la innovación. Cuadernos de gestión, 12, 51-58.

[9] García, C., Martínez, A. \& Fernández, R. (2010). Características del emprendedor influyentes en el proceso de creación empresarial y el éxito esperado. Revista Europea de Dirección y Economía de la Empresa, 19, 31-48.

[10] Inter-American Development Bank. (2014). BID y autoridades analizan políticas para impulsar el emprendimiento en la región. 21 de febrero de 2016, de Banco Interamericano de Desarrollo Sitio web: http://www.iadb.org/es/temas/competitividad-tecnologia-e-innovacion/bid-y-autoridades-analizan-politicaspara-impulsar-el-emprendimiento-en-la-region, 18237.html

[11] Inter-American Development Bank. (2015). BID aprueba US\$300 millones para seguridad social y eficiencia del gasto en salud de República Dominicana. 20 de febrero de 2016, de BID Sitio web: 
http://www.iadb.org/es/noticias/comunicados-de-prensa/2015-11-19/republica-dominicana-seguridad-social-ysalud,11327.html

[12] Khwaja, A. (2009). The importance of financial literacy for entrepreneurs. Available at https://www.entrepreneur.com/video/217601

[13] Kojo, E. (2010). Financial literacy and youth entrepreneurship in South Africa. African Journal of Economic and Management Studies, Vol. 1 Iss: 2, pp.164 - 182

[14] Lederman, D., Messina, J., Pienknagura, S., \& Rigolini, J. (2014). El Emprendimiento en América Latina: muchas empresas y poca innovación. Washington, Estados Unidos de América: Banco Mundial.

[15] Levin, A., Lin, C.F. \& Chu, C.S. (2002). Unit root tests in panel data: asymptotic and finite-sample properties. Journal of Econometrics 108 (2002) 1-24.

[16] López, P. (2010). Educación financiera, cuestión de sentido común en las personas. 19 de febrero de 2016, de El Economista Sitio web: Educación financiera, cuestión de sentido común en las personas

[17] Lupiáñez, L., Priede, T., \& López-Cózar, C. (2014). El emprendimiento como motor del crecimiento económico. Boletín Económico de ICE, 3048, 55-63.

[18] Mabhanda, W. (2015). Lack of financial literacy exacerbates SMEs' appalling state in Gweru city. Journal of Business Management Science. VOL 1 ISSUE 12 December 2015 Paper 2. ISSN: 2455-6661

[19] Marín, M. (2014). Educación financiera base del éxito de emprendedores. 18 de febrero de 2016, de El Economista Sitio web: http://eleconomista.com.mx/sistema-financiero/2014/05/13/educacion-financiera-baseexito-emprendedores

[20] National Commission for the Protection and Defense of Financial Services Users. (2012). La educación financiera es para ti. 20 de febrero de 2016, de CONDUSEF Sitio web: http://www.condusef.gob.mx/Revista/index.php/usuario-inteligente/277-la-educacion-financiera-es-para-ti

[21] National Commission for the Protection and Defense of Financial Services Users. (2013). Educación financiera, la clave. 20 de febrero de 2016, de CONDUSEF Sitio web: http://www.condusef.gob.mx/Revista/PDF-s/2013/162/entrevistas.pdf

[22] National Entrepeneur Observatory. (2013). Análisis transversal del gasto en políticas de apoyo a los emprendedores, MiPYMES. 20 de febrero de 2016, de Instituto Nacional del Emprendedor. Sitio web: http://www.mx.undp.org/content/dam/mexico/docs/Publicaciones/PublicacionesReduccionPobreza/one/Analisi stransversaldelgastoenpoliticasdeapoyoaemprendedoresyMiPyMEs.pdf

[23] Neck, H. (2014). La educación es importante para iniciar un negocio: Heidi Neck. 18 de febrero de 2016, de Innovación UNAM Sitio web: http://www.innovacion.unam.mx/entrevista_3.html

[24] Njoroge, R. (2013). Relationship between financial literacy and entrepreneurial success in Nairobi County Kenia. Available at http://chss.uonbi.ac.ke/sites/default/files/chss/NJOROGE\%20ROBERT-D61-758752012.pdf

[25] Nunoo, J. \& Andoh, F. (2012). Sustaining Small and Medium Enterprises through Financial Service Utilization: Does Financial Literacy Matter? Selected Paper prepared for presentation at the Agricultural \& Applied Economics Association's 2012 AAEA Annual Meeting, Seattle, Washington, August 12-14, 2012. Copyright 2012 by Nunoo, Jacob and Andoh, Francis Kwaw. All rights reserved. Readers may make verbatim copies of this document for non-commercial purposes by any means, provided this copyright notice appears on all such copies

[26] Singer, S. (2016). Falta educación financiera para el desarrollo de jóvenes emprendedores. 21 de febrero de 2016, de El Financiero-Bloomberg: http://www.elfinanciero.com.mx/tv/falta-educacion-financiera-para-eldesarrollo-de-jovenes-emprendedores-singer.html

[27] Small Business BC. (2016). What financial literacy can do for your business. Posted: September 30, 2015; updated: October 26, 2016. Available at: http://smallbusinessbc.ca/article/what-financial-literacy-can-do-foryour-business/ 
[28] Smyth, M. (2011). Educación financiera para todos: estrategias y buenas prácticas de educación financiera en la Unión Europea. 19 de febrero de 2016, de Comité Económico y Social Europeo Sitio web: http://www.eesc.europa.eu/resources/docs/qe-30-12-894-es.pdf

[29] Tiftik, H. (2014). A Survey of Entrepreneurial Tendencies Candidate Young Entrepreneurs: Foundation University Sample. Journal of Management Research. Vol. 6, No. 2. ISSN 1941-899X

[30] World Bank. (2015). Los empresarios jóvenes, como factores que impulsan el crecimiento sostenible. 20 de febrero de 2016, de Banco Mundial Sitio web: http://envivo.bancomundial.org/empresarios-jovenes-factoresque-impulsan-el-crecimiento-sostenible

[31] Yılmaz, E. y Sünbuil, A. (2008). Üniversite Öğrencilerine Yönelik Girişimcilik Ölçeğinin Geliştirilmesi. Selcuk University Social Sciences Institute Journal, 21. 